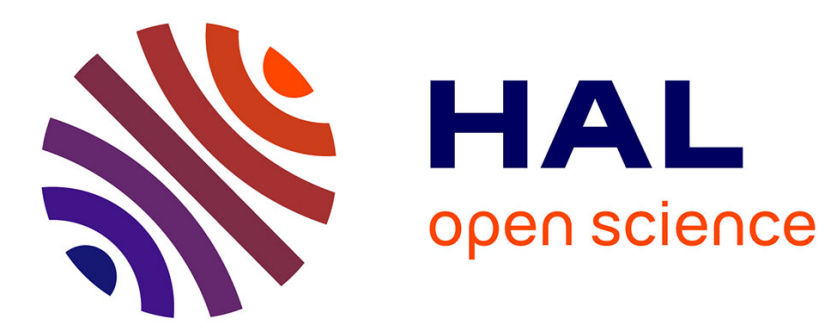

\title{
Pulsating combustion of ethylene in micro-channels with a controlled temperature gradient
}

Annalisa Di Stazio, Christian Chauveau, Guillaume Dayma, Philippe Dagaut

\section{To cite this version:}

Annalisa Di Stazio, Christian Chauveau, Guillaume Dayma, Philippe Dagaut. Pulsating combustion of ethylene in micro-channels with a controlled temperature gradient. 36th International Symposium on Combustion, Jul 2016, Seoul, South Korea. 10.13140/RG.2.2.14743.42407 . hal-02063471

\section{HAL Id: hal-02063471 \\ https://hal.science/hal-02063471}

Submitted on 11 Mar 2019

HAL is a multi-disciplinary open access archive for the deposit and dissemination of scientific research documents, whether they are published or not. The documents may come from teaching and research institutions in France or abroad, or from public or private research centers.
L'archive ouverte pluridisciplinaire HAL, est destinée au dépôt et à la diffusion de documents scientifiques de niveau recherche, publiés ou non, émanant des établissements d'enseignement et de recherche français ou étrangers, des laboratoires publics ou privés. 


\section{Pulsating combustion of ethylene in micro-channels with a controlled temperature gradient}

\section{The aim of our study}

Growing need to improve knowledge in the field of small-scale combustion for engineering applications (MEMS [1]).

- The new system can afford the study of the combustion characteristic of different fuels in very-lean conditions at micro-scale.

\section{The new device}

A cylindrical quartz tube was set between three heat sources and heated by hydrogen/oxygen flames. The temperature profile along the outer side of the reactor was measured by a FLIR A655sc infrared camera with an emissivity correction factor. A spectroscopy EMCCD camera (ProEM 1600) with a $\mathrm{CH}^{*}$ band-pass filter was used to detect the flame positions. $\mathrm{C}_{2} \mathrm{H}_{4} /$ air mixtures were supplied in a $1 \mathrm{~mm}$ internal diameter reactor at atmospheric pressure.

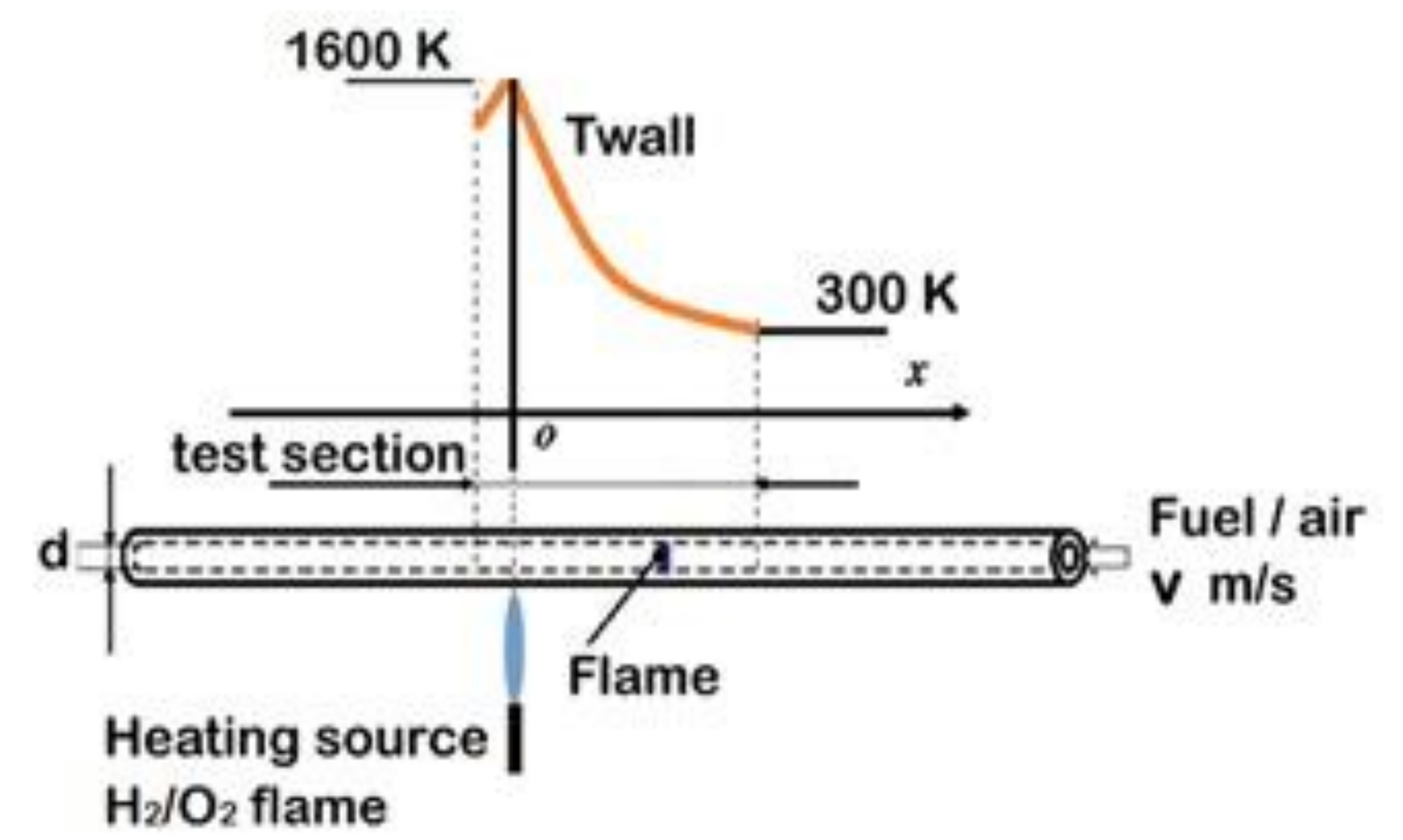

\section{A. Di Stazio, C. Chauveau*, G. Dayma, P. Dagaut}

Centre National de la Recherche Scientifique

Institut de Combustion Aérothermique Réactivité et Environnement 45071 Orléans cedex 2, France

*christian.chauveau@cnrs-orleans.fr

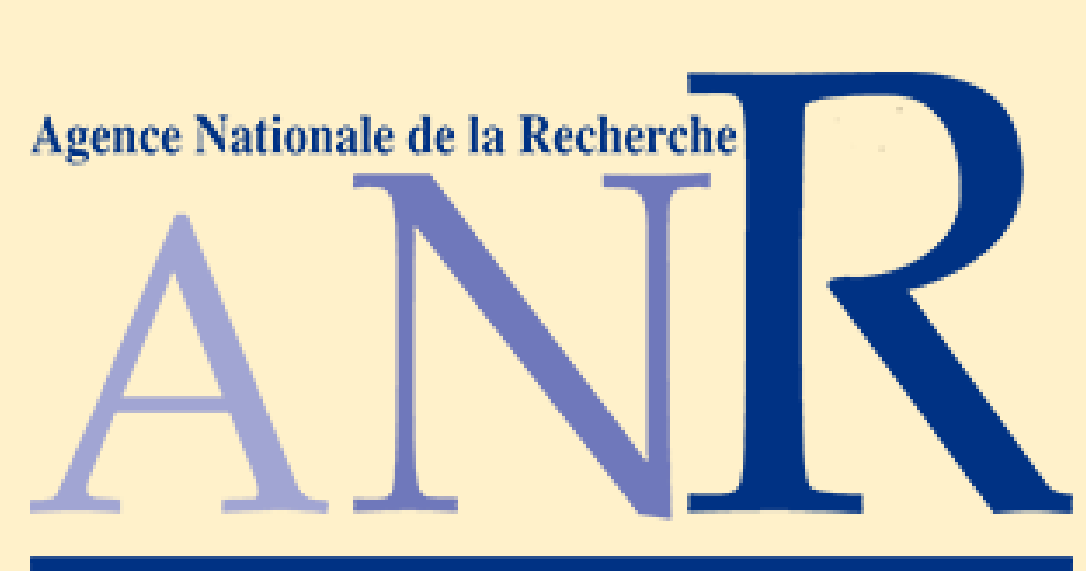

\section{Equivalence ratio effect and FREI dynamics}

Flame position defined at the wall temperature as a function of the mixture flow velocity at various equivalence ratios: 0.3 (grey), 0.4 (blue), 0.7 (orange), 0.9 (red), 1 (black), 1.1 (green), 1.3 (purple), 1.5 (pink).

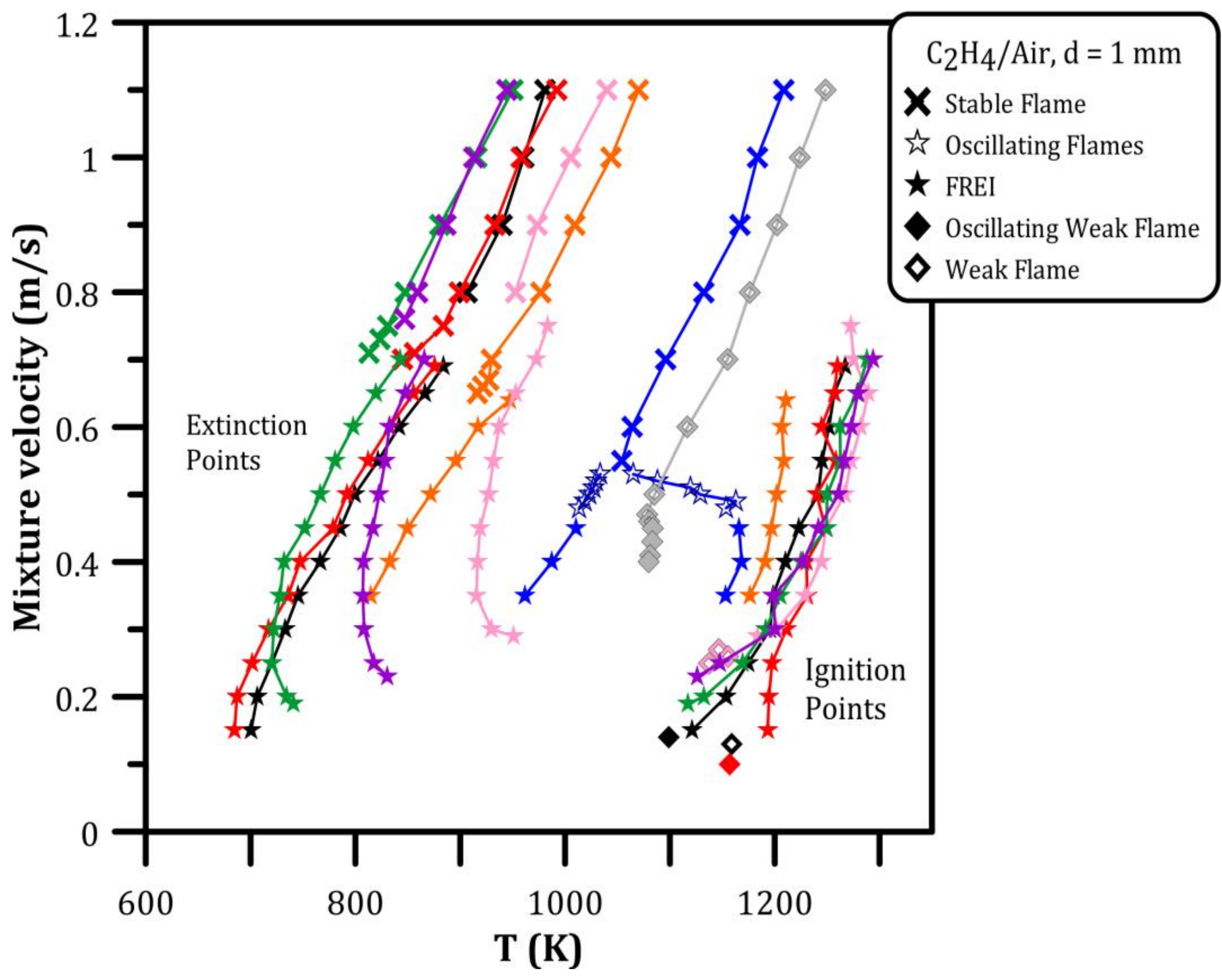

Using the Fourier function on the spectral cross-section of the $\mathrm{CH}$ signal, it is possible to determine the flame frequencies. The results obtained with

$\mathrm{CH}_{4} /$ Air in a $1 \mathrm{~mm}$ internal diameter reactor are also reported.

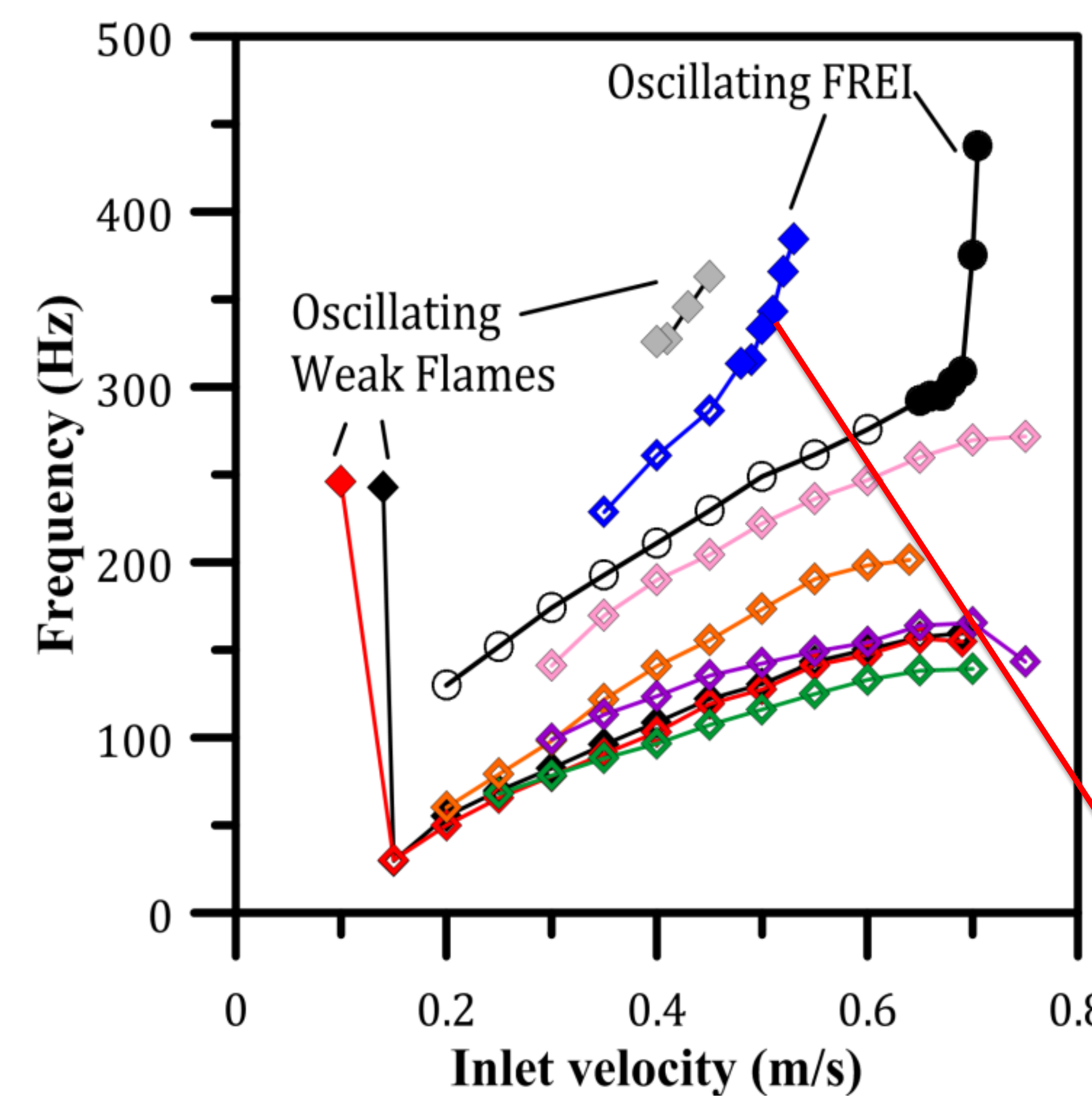

Oscillating FREI were observed in the transition region between stable flames and FREI at an equivalence ratio of 0.4 . These flames oscillate at high frequency but do not extinguish (the $\mathrm{CH}^{*}$ signal does not go to zero). The oscillation amplitude increases when decreasing the inlet velocity until getting a typical FREI. The mathematical model proposed by Jackson et al. [4] was able to predict these instabilities that are due to the heat losses through the tube wall.
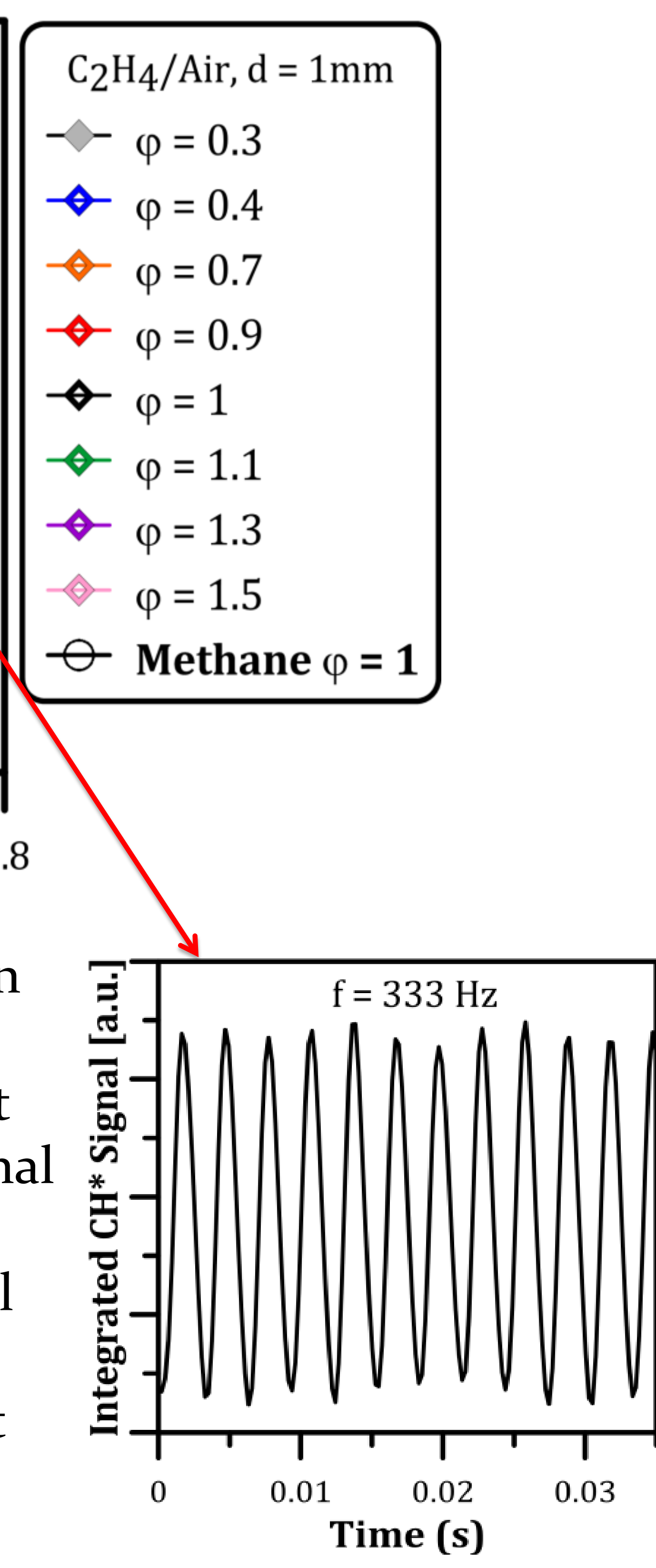

The presence of multiple $\mathbf{C H}^{*}$ peaks was detected during FREI propagation at high equivalence ratio $(\varphi \geq 1)$ : this is probably due to the combustion of remaining unburned species behind the main flame front. Previous studies $[5,6]$ confirms the existence of splitting flames for methane/air mixtures.

\section{References}

[1] A.C. Fernandez-Pello, Proc. Combust. Inst., 29 (1) (2002) 883-899.

[2] Y. Ju, K. Maruta, Prog. Energy Combust. Sci., 37 (6) (2011) 669-715.

[3] A. Cavaliere, M. de Joannon, Prog. Energy Combust. Sci., 30 (4) (2004) 329-366.

[4] T.L. Jackson, J. Buckmaster, Z. Lu, D.C. Kyritsis, L. Massa, Proc. Combust. Inst., 31 (1) (2007) 955-962

[5] A. Fan, S.S. Minaev, E.V. Sereshchenko, Y. Tsuboi, H. Oshibe, H. Nakamura, K. Maruta, Combustion,

Explosion, and Shock Waves, 45 (3) (2009) 245-250.

[6] S. Minaev, E.V. Sereshchenko, R.V. Fursenko, A. Fan, K. Maruta, Combustion, Explosion, and Shock

\section{Acknowledgements}

The research leading to these results has received funding from the European Research Council under the European Community's Seventh Framework Programme (FP7/2007-2013) / ERC grant agreement $n^{\circ} 291049$ 2 G-CSafe and from the Agence Nationale de la Recherche (ANR-12-VPTT-0008) 